\title{
Katolik İspanyol İktidarında Endülüs Müslümanları'nın Kimlik Mücadelesi: Moriskolar Örneği
}

\section{Feridun BILGIN*}

\author{
Andalusian Muslims' Struggle for Identity \\ in Catholic Spanish Ruling: The Moors Case
}

Citation/@: Bilgin, Feridun, (2014). Andalusian Muslims' Struggle for Identity in Catholic Spanish Ruling: The Moors Case, Milel ve Nihal, 11 (1), 5169.

Abstract: The Catholic Spanish Government in the 16th century introduced a special education program in schools and churches for Andalusian Muslims (Moors) to give them a new identity. This program was carried out within the legal framework and was announced through royal edicts and was later used as a tool by the Courts of the Inquisition for the pursuit, detention and punishment of Moors. Both the individual and social space for Andalusian Muslims was in the process of elimination for this reason. Muslims have tried "not to forget" their Islamic rituals, which are became part of their identity, and carefully refrained from eating pork, drinking wine and showing respect to Christian clerics, as these were signs of Christianity. In this context, in our article, the Catholic Power used methods and applied tools to ensure his power, are evaluated in the light of one of postmodern theorists Michel Foucault's conceptualizations. It's brought to light some examples about Moors, which resist to compulsions and seek to protect their identity.

* Yard. Doç. Dr., Mardin Artuklu Üniversitesi, Edebiyat Fakültesi, Tarih Bölümü [feridunb@gmail.com] 
Key Words: Andalusian Muslims (Moors) Catholic Spain Goverment, power, assimilation, identity, forgetting, remembrance.

Atıf/C: Bilgin, Feridun, (2014). Katolik İspanyol İktidarında Endülüs Müslümanları'nın Kimlik Mücadelesi: Moriskolar Örneği, Milel ve Nihal, 11 (1), 51-69.

Öz: XVI. asır Katolik İspanyol Yönetimi, Endülüs Müslümanları'na (Moriskolar) yeni bir kimlik kazandırmak için kilise ve okullarda özel eğitim-öğretim programları hazırlamıştır. Bu programların yasal çerçevede icrâ edilmesi için kraliyet fermanları yayımlanmış ve engizisyon mahkemeleri Moriskolar'ı takip, tevkif ve cezalandırma da birer araç olarak kullanılmıştır. Moriskolar, bireysel ve toplumsal alandan tasfiye edilmeye çalışılan İslâmî ritüelleri kimliklerinin bir parçası haline getirerek "unutmanın" önüne geçmeye çalışmış, domuz eti yeme, şarap içme ve Hıristiyan din adamlarına saygı gösterme gibi, Hıristiyanlığın işareti kabul edilen hususlardan özenle kaçınmışlardır. Bu çerçevede, makalemizde, Katolik iktidarın kullandığı yöntemler ve başvurduğu araçlar önemli portmodern kuramcılardan biri olan Michel Foucault'un kavramlaştırmaları kullanılarak değerlendirilmekte ve Moriskolar'ın baskılara karşı geliştirdikleri direniş örneklerine ışık tutulmaktadır.

Anahtar Kelimeler: Endülüs Müslümanları (Moriskolar), Katolik İspanya yönetimi, iktidar, asimilasyon, kimlik, hatırlama, unutma.

\section{Giriş}

Biz bu çalışmamızda Michel Foucault'un iktidarın tanımı ve iktidarın sağlanmasına yönelik ortaya koyduğu "iktidarın gözü", "dışa kapatma", "gözetleme", “ödüllendirme”, "cezalandırma" ve "disiplin teknolojisi" kavramları üzerinden Endülüs Müslümanları'nın (Moriskolar) ${ }^{1}$, Katolik İspanyol yönetiminde sosyo-kültürel ve dinî kimliklerini koruma ve yaşatma mücadelesini ele alacağı. Bilindiği üzere, Endülüs Müslümanları'nın İspanya'daki son emîrliği olan Benî Ahmer (Nasrîler) Devleti'nin yıkılışından (898/1492) sonra,

1 Morisko: "Moro" kelimesinin küçültülmüş şekli olarak "Küçük Müslümanlar" anlamına geldiği düşünülmektedir. Müslümanlar'ın zayıf, güçsüz ve zelil olduklarını vurgulamak maksadıyla Hıristiyanlar tarafından kullanılmış bir kelimedir. Günümüz tarihçileri ise, "Morisco" kelimesini, İspanya'da, Müslümanlar'ın soyundan gelen ve baskıyla din değiştirmek zorunda kalıp Hıristiyan olan Müslümanlar için kullanırlar, geniş bilgi için bk. E. Lévi-Provençal "Moors". Encyclopaedia of Islam. P. Bearman ,Th. Bianquis, C. E. Bosworth, E. van Donzel and W. P. Heinrichs (Ed.). Brill 2008, VII, 235-236; Mikel de Epalza Los moriscos antes y después de la expulsión, Editorial Mapfre, Madrid 1992; http://www.cervantesvirtual.com/FichaObra (12 Eylül 2008), s. 8; Biz de makalemizde baskı altında kalan Endülüs Müslümanları için "Morisko" kelimelerini kullanacağız. 
Katolik İspanyol İktidarınđa Enđülüs Müslümanları'nın Kimlik Mücadelesi: Moriskolar Örneoği

Müslümanlar Hıristiyan bir idarenin hâkimiyetine girmiştir. Önceleri, Katolik İspanyol yönetimi tarafından dinî ve sosyo-kültürel kimliklerini korumalarına izin verilen Müslümanlara, bir süre sonra ya din değiştirmeleri ya da İspanya'yı terk etmeleri konusunda baskı yapılmıştır. İmkanı olanların bir kısmı İspanya'yı terk etse de büyük çoğunluğu İspanya' da kalmayı ve baskılara direnmeyi tercih etmiştir. Yaklaşık 120 yıllık bir direnişin ardından "son sürgün" olarak adlandırılan süreçte İspanya'dan tamamen çıkarılmışlardır (1018-1023/1609-1614). Sürgün edilen Moriskolar Kuzey Afrika, Avrupa ve Balkanlar ile Anadolu topraklarına göç etmiştir. Göç ettikleri coğrafyalarda tutunamayanların bir kısmı gizlece İspanya'ya tekrar dönecektir. ${ }^{2}$

Michel Foucault, iktidarı, bir kısım insanların başka insanların davranışlarını az çok belirleyebilmeleri olarak tanımlar. Ona göre, iktidarın sağlanmasının iki ön şartı vardır. Bunlardan birincisi "başkaldırma/reddetme" nin var olması ${ }^{3}$, ikincisi ise bir öznenin (tebaanın) yaratılmasıdır. Bu duruma göre, denetim ve bağımlılık yoluyla başka birine itaat eden özne-vicdan ve bilgi yoluyla kendi varlığına bağlanmış olan özne-iktidarın sağlanmasına yol açar. "Birbirine yolaçan ve birbirine cevap veren bir eylemler bütünü..." olan iktidar, kendisini ilişkiler ağı üzerinden, başkalarının eylemleri üzerinde eylemde bulunarak kurmaktadır.

Foucault'un ifade ettiği iktidar olma mantığı, en fazla, yine onun "pastoral iktidar" olarak isimlendirdiği iktidar biçiminde kendisini göstermektedir. Foucault, bu iktidar biçiminin Hıristiyan müesseselerinde bulunan eski bir iktidar tekniği olduğunu, bütün olarak toplumu değil, toplumda var olan her bireyi ölümüne kadar gözetlemeyi gaye edindiğini belirterek insanların zihin ve gönüllerinde ne olduğunu bilmeden, ruhlarına nüfûz edenleri öğrenmeden yani, vicdan bilgisine sahip olmadan ve bu bilgiye yön verme becerisine sahip olmadan uygulanamayacağından bahseder. Ona göre, Pastoral iktidar anlayışı, tesis edilen kurumlarda yürütülen faaliyetler vasitasıyla (kilise, okul ve benzeri kurumlarda), her bireyin bilgi

2 Moriskolar'ın göç ettikleri coğraflar için bk. Feridun Bilgin, "Endülüs'te Kalan Son Müslümanların (Moriskolar) İspanya'dan Sürgünü (1609-1614)” Dinbilimleri Akademik Araştırmalar Dergisi, C. XIII, sayı: II, s.53-54.

3 Michel Foucault, Özne ve İktidar, Çev.: Işık Ergüden-Osman Akınay, Ayrıntı Yayınları, İstanbul 2011, s. 55. 
düzeyini ve değerini gösteren farklılıklar ile dışa kapatma, gözetleme, ödüllendirme, cezalandırma ve hiyerarşi piramidi gibi iktidar süreçleriyle gerçekleşir. Buradaki temel amaç bireyin ve/ya grubun "davranışlarını yönlendirmek" ve ortaya çıkacak muhtemel sonuçları düzene sokmaktır. ${ }^{4}$

\section{A. Katolik İktidarın Sağlanması}

Foucault'un pastoral iktidar anlayışına dair tespitleri, XVI. asır Katolik İspanyol yönetim tarzını ve anlayışını anlamamız açısından aydınlatıcıdır. Sözkonusu yönetim iktidarının sağlanması amacıyla, Moriskolar üzerinde tüm iktidar süreçlerini (dışa kapatma, gözetleme, ödüllendirme ve cezalandırma) tatbik etmiştir. Bu bağlamda, öncelikle, Müslümanların yoğun olarak yaşadıkları Gırnata (Granada) şehrinde, küçük-büyük 20 kilise inşâ etmiştir. ${ }^{5}$ Müslümanların gerçek birer Hıristiyan olmalarını sağlamak amacıyla bu kiliselerde başlatılan eğitim ve öğretim faaliyetlerinin düzenli yürütülmesi için de Katolik akidesini/öğretisini anlatan ilmihaller yazılmıştır. Bu ilmihallerden birisi de Her Hiristiyanın Bilmesi Gerekenle Ilgili Özet Ö̆greti, Diğer Faydalı Bilgilerle Beraber (Breve y muy provechosa doctrina de lo que debe saber todo cristiano con otros tradatos muy provechosos) ismini taşımaktayd1. ${ }^{6}$ Yine, Pedro Patricio Mey tarafından yazılan Yeni Din Değiş̧tiren Moriskolar'ın Eğitimi İçin İlmihâl (Catecismo para instrucion de los nuevamente convertidos de Moros) isimli eser bunlardan bir diğeridir.7

Moriskolar'ın kiliselerdeki eğitim-öğretim faaliyetlerine düzenli olarak katılımlarının sağlanması amacıyla, mahallelerdeki kilise papazlarından gerekli hassasiyeti göstermeleri, yoklamaların aksatılmadan alınması, katılım noktasında ihmalkâr davrananların engizisyon mahkemesine bildirilmesi gibi uygulamalar İspanyol

Foucault, Özne ve İktidar, s. 63, 65, 70, 71, 74.

Angel A. Amy Moreno, The Spanish Treatment of Moriscos as a Model for the Treatment of Native Americans, Yayımlanmamış Doktora Tezi, Boston University 1982, s. 88

6 Feridun Bilgin, Nasrîler (Ben̂̂ Ahmer) Sonrasında Endülüs'teki Müslümanlar (Moriskolar), Yayımlanmamış Doktora Tezi, MarmaraÜniversitesi Sosyal Bilimler Enstitüsü, İstanbul 2010, s.66.

7 Lours Cardaillac, el-Moriskiyyûne'l-Endelüsiyyûne'l Mesihiyyûn, el-Mücâbihâtü'lCedeliyye (1492-1640), Trc.: Abdülcelil Temîmî Zaghouan 1989, s.48. 
Katolik İspanyol İktidarınđa Enđülüs Müslümanları'nın Kimlik Mücadelesi: Moriskolar Örneoği yönetimi tarafından büyük bir titizlikle takip edilmiştir. ${ }^{8}$ Kiliselerdeki eğitim-öğretim faaliyetlerinin yanısıra, Morisko çocuklarının eğitimi için din adamlarının teşviki ve devlet adamlarının çalışmalarıyla özel okullar açılmıştır. Bu okullardan bazıları, 1526'da Gırnata Şehir Meclisi'nin kararıyla, Gırnata, Meriye (Almaría) ve Kadis'te (Cadíz) eğitim-öğretim faaliyetlerine başlamıştır. ${ }^{9}$

Foucault'nun ikitidarın en önemli araçlarından biri olarak gördüğü ve toplumun en küçük birimine kadar denetlenmesini sağlayan "disiplin teknolojisi" 10, Moriskolar üzerinde tavizsiz bir şekilde uygulanmıştır. Moriskolar'ın davranışları gözetlenmiş, becerileri denetlenmiş, performans ve yetenekleri geliştirilmeye çalışılmıştır. Katolik iktidarın sağlanması için, dinî öğretilerin birey ve toplumun ruh derinliklerine ve ilişkilerine nüfuz etmesi gerekiyordu. Bu amaçla, ihtidâ etmiş kabul edilen Moriskolar'ın yeni dinin (Katoliklik) siyasî ve dinî otoritelerini her zaman ve zeminde benimsediklerini göstermeleri istenmiştir.

Foucault, "gözetleme"yi iktidarın sürekliliğini sağlayan bir yöntem olarak görür. Çünkü, sürekli gözetlendiğini, denetlendiğini düşünen bir kimse kötülük yapma gücünü ve kötülük isteme düşüncesini neredeyse yok eder. ${ }^{11}$ Sürekli gözetleyen bir bakışın varlığını üzerinde hisseden herkes, bunu öylesine içsel bir hale getirir ki, sonunda kendisini gözetleme noktasına vardırır; böylece, herkes kendi üzerinde ve kendine karşı gözetleme pozisyonuna geçer. ${ }^{12}$ "Sapık bir inanca mensup oldukları" inanciyla Hiristiyan mahallelerine dağıtılan Moriskolar'ın "takiyye" yapmak zorunda kalmaları ciddi bir şekilde "gözetleme" altında bulunduklarını göstermektedir. Komşuları olan Hıristiyan aileler tarafından bilhassa, Ramazan ayında yemeğe davet edilmeleri, iştah eksikliği mazeretiyle davete icabet etmeyenlerin engizisyon mahkemesine ihbar edilmeleri sıra-

8 Moriskolar engizisyon mahkemesine "şeytanın mahkemesi" ismini vermişlerdi, bk. Abdullah Muhammed. Cemâleddîn, el-Müslimûne'l-münassârûn evi'l-Mûriskiyyûne'l-Endelüsiyyûn: Safha mühime min târîhi'l-müslimîn fi'l-Endelüs, Dârüs'sSahve, Kāhire 1991, s.374.

9 Cemâleddîn, el-Müslimûne'l-münassârûn, s.367.

10 Foucault, Özne ve İktidar, s.149-150.

11 Michel Foucault, İktidarın Gözü, Çev.: Işık Ergüden, Ayrıntı Yayınları, İstanbul 2012, s.92.

12 Foucault, İktidarın Gözü, s.95. 
dan bir durumdur. 1590-1591'de Belensiye (Valencía) yakınlarındaki Misletâ köyünde 100 dava, Karliyet köyünde ise 200 dava Ramazan orucuyla ilgili açılmış ve 40 Morisko ailesi oruç tutmakla suçlanmıştır. ${ }^{13}$ Engizisyon mahkemeleri, hem Hıristiyan komşularından hem de Moriskolar'ın aile fertlerinden islâmî örf ve adetlere riâyet edenlerin ihbar edilmesini istemiştir. ${ }^{14}$ İhbarda bulunanlar ise her defasında ödüllendirilmiştir.

Foucault'nun bir iktidar süreci olarak değerlendirdiği "cezalandırma" Moriskolar üzerinde değişik şekillerde tatbik edilmiştir. Binlerce misal arasında burada bir kaçına değinebiliriz; İsabel isimli Morisko, kız kardeşi ve annesini ihbar etmemesi nedeniyle yakılarak öldürülmüştür. Kurtuba'da (Cordoba) ikâmet eden İsabel Perez isimli kadın Ramazan ayında sahura kalktığı gerekçesiyle engizisyon mahkemesinde yargılanmıştır. ${ }^{15}$ Dönemin İspanyol yazarları ispiyoncu olmayan Moriskolar'1 "kötü huylu" kişiler olarak kabul ettiklerinden onların münkîr ve aforoz edilmiş kafirler olarak yakıldıklarını belirtirler. ${ }^{16}$ Cezalandırılanlar arasında sahura kalktığı gerekçesiyle engizisyon mahkemesinde yargılanan Kurtuba'lı Juan Herrador isimli erkek ile Tuleytûla' da üzüm yetiştiriciliği yaptığı ve bunlardan şarap imal ettiği halde şarap içmemekle engizisyon tarafından suçlanan bir başka Morisko da vard1. ${ }^{17}$ Hatta, "bismillah" demek, Müslümanlık işareti olarak değerlendirildiğinden sırf bundan dolayı birçok Morisko engizisyon mahkemesinde yargılanmıştır. Juan Grande isimli şahıs işe başlarken "bismillah" demekle suçlanmiştır. ${ }^{18}$ Yine, Tuleytula kentinden olan Juan de Burgos isimli morisko ise, Cuma gecesi, evinde yakınlarını topladığı ve bu toplantıda

13 Cemâleddin, el-Müslimûne'l-münassârûn, s.375.

14 Abdülcelil Temîmî, "Vâkiu ve'l-Mustakbelu bahsu 'an Târîhi'l-Moriskiyyin elEndelüsiyyîn, Las Practicas Musulmanes de Los Moriscos Andaluces (14921609)", Actas de 111 simposio internacional de estudios moriscos, Zaghouan 1991, s.41.

15 Juan Aranda Doncel, “Las Practicas Musulmanas de los Moriscos Anadaluces a Traves de las Relaciones de Causas del Tribunal de la Inquisicion de Cordoba", Las Practicas Musulmanas de los moriscos Andaluces (1492-1609)", Actas de 111 simposio internacional de estudıos moriscos, Zaghouan, November 1991, s.17; Bilgin, Endülüs'teki Müslümanlar (Moriskolar), s.14.

16 H. Charles Lea, İspanya Müslümanları, Hıristiyanlaştırılmaları ve Sürülmeleri, Çev.: Abdullah Davudoğlu, Inkılâb Yayınları, İstanbul 2006, s. 62, dn.30, Bilgin, Endülüs'teki Müslümanlar (Moriskolar), s.75.

17 Cardaillac, Louis, Moriscos y Cristianos un Enfrentamiento Polemico (1492-1640), Fondo de Cultura Economica, Madrid 1979, s. 33.

18 Cardaillac, Moriscos y Cristianos, s.31 
Katolik İspanyol İktidarınđa Enđülüs Müslümanları'nın Kimlik Mücadelesi: Moriskolar Örneoği

Mağribîler'e ait şarkı ve türküleri söyledikleri ve küsküs ${ }^{19}$ isimli yemeği yedikleri gerekçesiyle yargılanmıştır. ${ }^{20}$

1546 'da Ciudad Real şehrine bağlı Bolan Köyü'nde Alonso Almerique isimli Morisko, Hz. Muhammed'in (s.a.v.) dinine mensup olması, domuz eti yememesi ve şarap içmemesi sebebiyle engizisyon tarafından suçlanmıştır. Aynı köydeki Lope Almerique isimli şahıs akşam yemeğine arkadaşları tarafından davet edilip domuz etini yememe sebebi kendisine sorulunca, atalarının da domuz etini yemediğini ifade etmiştir. ${ }^{21}$ Moriskolar'ın gündelik hayattaki davranış tarzları da baskı altına alınmıştır. Mesela, Tuleytula'da mukîm Juan de Flores isimli Morisko, Hz. Muhammed'e (s.a.v.) inanmak, sandalyede oturmamak ve masada yemek yememekle suçlanmıştir. ${ }^{22}$

Foucault'nun bahsettiği şekilde "gözetim" faaliyetlerinin Moriskolar üzerinde icrâ edildiği bir diğer önemli alan ise doğumlardır. Kilise öğretisine göre, her doğan çocuğun günahlarından arındırılması ve kilisenin onları daha sonraki hayatlarında yargılayabilmesi için vaftiz edilmesi gerekmektedir. Bu amaçla, Morisko kadınlarının ebelik yapmaları yasaklanmış, doğacak her çocuğun Hıristiyan bir ebe tarafından doğumunun gerçekleştirilmesi, mahalle papazlarına ve yetkililere doğum haberinin bildirilmesi zorunluluğu getirilmiş, buna riâyet etmeyenlere para cezaları verilmiştir. ${ }^{23}$

Katolik İspanyol yönetiminin asimilasyon ve iktidarı sağlamaya yönelik yöntemlerinden biri de dişa kapatma yöntemidir. Foucault bu durumu hapishane olarak kavramsallaştırır. Ona göre, hapishane, normların dışına çıkmış ruhları terbiye etmek ve iyileştirmek amacıyla kurulmuştur, asıl hedef ise, “Büyük Kapatılma”nın

19 Küsküs: Kuzey Afrika'da yaygın olarak irmikle yapılan ve buharla pişen yemek türlerinden biridir, bk. Cardaillac, Moriscos y Cristianos, s. 20, 25.

20 Cardaillac, Moriscos y Cristianos, s.36.

21 Longas, La Vida Religiosa de Los Moriscos, Universidad de Granada, Granada 1998, s. 263, s. 182, dn.6; Bilgin, Endülüs'teki Müslümanlar (Moriskolar), s.177.

22 Cardaillac, Moriscos y Cristianos, s.27.

23 Lea, İspanya Müslümanları, s.100-101; Valencia'nın köy evlerinden birinde banyodaki suyun defne, biberiye ve portakal ile kokulandırılmasının bile kontrol edilmesi, gözetim faaliyetlerinin geldiği korkunç boyutunu göstermesi açısından iyi bir örnektir, bk. Cardaillac, Moriscos y Cristianos, s.38. 
gerçekleştirildiği insan ruhudur. ${ }^{24}$ Moriskolar'ın "morería" 25 ismi verilen toplama merkezlerinde/mahallelerde, toplumdan uzak bir yerde, bir araya getirilmeleri iktidarın spesifik bir alanda gerçekleştirilmesine iyi bir örnek teşkil etmektedir.

Hıristiyan toplumu arasında dağıtılmaları ve sürekli gözetim altında tutulmalarına rağmen, yeterince asimile olmadıklarına dair İspanyol idarecilerindeki kuvvetli kanaat, bir süre sonra Moriskolar'ın hem kendi aralarındaki iletişimlerini, hem de diş dünyayla bağlantılarını kesmek amacıyla, yaşadıkları bölgelerden sürgün edilerek, uzak coğrafyalarda tecrîd edilmiş mahallelerde (morería) yaşamalarını zorunlu hale getirmiştir. Bu amaç için yayımlanmış kraliyet fermanlarından biri de II. Philip (1556-1598) tarafından ç1karılmıştır. Bu fermana göre; Gırnata, Vega, Lecrîn Vadisi ve Mâleka'daki (Malaga) Moriskolar'ın, Extramadura ve Galicia'ya bölgelerine, Vâdîâş, Beyzâ (Baeza) ve Almanzora Nehri civârında yaşayanların Eski Kastilya'nın Leon bölgesine kadar olan bir sahaya, Meriye ve mücâvir alanlarındakilerin ise İşbîliye'ye (Sevilla) taşınması emredilmiş, hiçbir Morisko'nun Mürsiye (Murcía), Belensiye, Girnata ve civâr bölgelerine gitmesine izin verilmeyeceği belirtilmiştir. ${ }^{26}$ Moriskolar'ın dış dünya ile (Osmanlı ve Kuzey Afrika) irtibat kurma ihtimali olan yerlerden çıkarılması -Belensiye sahil bölgelerinde oturanlar- ve ülkenin iç kesimlerine tehcîr edilmeleri uygulamaya konulan bir diğer önemli husustu. ${ }^{27}$

24 Michel Foucault, Büyük Kapatılma, Çev.: Işık Ergüden, Ferda Keskin, Ayrıntı Yayınları, İstanbul 2011, s.19.

25 Muhammed Abdullah İnân, Nihâyetü'l-Endelüs ve târîhu'l-Arabi'l-Mütenassirîn, Mektebetü'l-Hancî, Kahire 1987, s.320; Lea, İspanya Müslümanlarl, s.202; İspanyol Kraliyet Akademisi'nin (Real Academia Española) sözlüğünde "Morería" kelimesinin karşılığı olarak "Moriskolar'ın yaşadı̆̆ı mahalle ve Moriskolar'a ait bölge ve ülke“ anlamları verilir, bk. http://lema.rae.es/drae/?val=morer\%C3\%ADa (16.07.2014). Belensiye'nin işgali sonrasında bu şehirdeki "Morería" için bk., José Rodrigo Pertegás, “La morería de Valencia. Ensayo de descripción topográfico histórica de la misma", Edición digital a partir de Boletín de la Real Academia de la Historia, tomo 86 (1925), Biblioteca Nacional, Madrid 2010, s.230.

26 Fernand Braudel, Akdeniz ve Akdeniz Dünyası, Çev.: Mehmet Ali Kılıçbay, İmge Yayınları, İstanbul 1994, II, 164; Ali el-Muntasır Kettanî, İnbiâsü'l-İslâm fi'l-Endelüs, Câmiatü'l-İslâmiyyeti'l-Âlemiyye, İslamabad 1992, s.72; Cemâleddin, el-Müslimûne'l-münassârûn, s.106; Bilgin, s.154.

27 Antonio Domínguez Ortiz- Bernard Vincent, Târîhu Müslimi'l-Endelüs - Mûriskiyyûn (Hayâtu ve Me'sâtu Ekâliyye, Trc.: A.Salih Taha, Katar 1998, s. 84; Bilgin, Endülüs'teki Müslümanlar (Moriskolar), s.158. 
Katolik İspanyol İktidarınđa Enđülüs Müslümanları'nın Kimlik Mücadelesi: Moriskolar Örneoği

\section{B. Moriskolar'ın Kimliklerini Koruma Mücadelesi \\ a. Unutturma}

Foucault, hakikate kayıtsız kalan iktidardan daha tutarsız bir şeyin olmadığını fakat, hakikatin kendi tekelinde olduğunu iddia eden bir iktidardan da daha tehlikeli bir şey bulunmadığını ifade eder. ${ }^{28}$ İktidar, toplumu dönüştürmek isterken ona yeni bir ideoloji, din ve kültür empoze eder. Bunu yaparken toplumu öz bilincinden koparmak için sistemli bir şekilde "unutturma" yöntemini kullanır. ${ }^{29} \mathrm{Ka}-$ tolik İspanyol yönetimi ve kilise çevreleri de hakikatın kendi inançlarında bulunduğunu, bu inanç dışındaki diğer dinlerin (Müslümanlık ve Yahudilik) ve mezheplerin (Protestanlar ve Kalvinistler) "sapkın" olduğunu iddia etmiştir.

Moriskolar'in toplumsal belleklerini yok etmek için örf ve âdetlerine, inançlarına ait ne varsa yasaklama yoluna gidilmiştir. Bilhassa, simgesel nitelik taşıyan türden kurallarca yönetilen etkinlikler anlatılmak istendiğinde kullanılan ritüeller (törenler) yasaklanmıştır. Antropolojik açıdan ritüeller içerden gelen anlık zorlamalarla değil, belli başlı duyguları bilinçli bir şekilde dile getirmek için icra edilirler. ${ }^{30} \mathrm{Bu}$ kapsamda; Moriskolar'ın toplumsal görünürlüklerinin işareti olan Arap dilinin konuşulması ve bu dille eğitimöğretim faaliyetlerinin icra edilmesi, Araplar'a mahsus olan elbiselerin giyilmesi, terzilerin bu tarz elbise dikmeleri ve takıların takılması, eller ve ayaklar ile kadınların başlarına kına yakmaları, Mağribî isimlerin çocuklara verilmesi ${ }^{31}$ ve kabile isimlerine atfen

28 Michel Foucault, Özne ve İkitidar, s.97

29 Paul Connerton, Toplumlar Nasıl Anımsar?, Çev.: Alaeddin Şenel, Ayrıntı Yayınları, İstanbul 1999, s.27; belleğin toplumsal çerçevelerinden biri kolektif hatırlama ise diğer tarafı kolektif unutmadır. Bu iki unsur bir madalyonun iki yüzü gibi kolektif belleği oluştururlar, bk. Ahenk Yılmaz, "Bellek Topografyasında Özgürlük: Gelibolu Savaş Alanları ve Mekânsal Bir Deneyim Olarak Hatırlama", Nasıl Hatırlıyoruz? Türkiye'de Bellek Çalışmaları içinde, Haz..: Leyla Neyzi, Türkiye İş Bankası Kültür Yayınları, İstanbul 2011, s.189.

30 Connerton, Toplumlar Nasul Anımsar?, s.70-71.

31 Luis de Marmol Carvajal, Historia de Rebellion y Castigo de los Moriscos del Reino de Granada, Madrid 1797, I, 141-142; Jaime Bleda, Coronica de Los Moriscos de España, Universitad de Valencia, Valencia 2001, s. 656; Epalza, Los moriscos antes y después de la expulsión, s. 46; Pedro Longas, La Vida Religiosa de Los Moriscos, s. XLI; İnân, Nihâye, s. 353-354; Antonio Gallego Burin y Alfonso Gámir Sandoval, Los Moriscos del Reino de Granada, Según Sínodo de Guadix de 1554, Granada 1996, s. 21-22. 
kullanılan "İbn" kelimesinin kullanılması yasaklanmıştır. ${ }^{32}$ Ayrıca, her doğan çocuğun vaftiz edilmesine özel önem verilerek, Moriskolar'ın çocuklarına isim takma merâsimleri takibat altına alınmış, düğünlerde Mağribliler'e has Oyun (zambra) ve şarkılar (leila), yasaklanmıştır. ${ }^{33}$

İspanya'daki farklı inanç kesimleri içerisinde hem yönetim tecrübeleri hem de nüfus yoğunlukları itibariyle önemli bir potansiyele sahip olan Moriskolar'ın Hıristiyan nüfusu ve inancı içinde eritilmesi İspanyol yönetiminin öncelikli hedefleri arasında yer almıştır. Bu amaçla, hem resmî düzeydeki emir ve yasaklarla (fermanlarla), hem de İspanyol Katolik kilisesinin eğitim-öğretim programları ve engisizyon mahkemesinin koğuşturma ve cezalandırmalarıyla Morisko toplumu İslâmî köklerinden koparılmaya çalışılmıştır.

Arapça konuşma ve yazmanın yasaklanması, Endülüs yazılı hafızasının yok olmasına neden olmuştur. Gırnata'nın işgali sonrasında başlatılan Hıristiyanlaştırma faaliyetleri kapsamında dönemin Girnata başpiskoposu olan Kardinal Cisneros onbinlerce Arapça kitabı meydanlarda yak(tır)mıştır. ${ }^{34}$ Cisneros kitap katliamını yaparak Moriskolar'ın kültür ve tarihleriyle olan bağlarını keseceğini düşünmüştür. Sosyal yaşamın kurulmasında ve sürdürülmesinde en önemli araç olan dilin/Arapça'nın yasaklanması Moriskolar'ın toplumsal iletişimine vurulan önemli bir darbe olmuştur. Bu amaçla, 1565 'de çıkarılan bir kraliyet fermanında Arapça tüm belge ve kitapların 30 gün içerisinde yetkililere teslim edilmesi istenmiş, bu süre sonunda ihmalkâr davranların 20.000 Marevidî ile cezalandırılacakları ilan edilmiştir. Mesela; zamanında kitapları teslim etmeyen Gırnata'lı Diego Haron isimli şahıs cezalandırılmıştır. ${ }^{35}$

Moriskolar'ın, sadece, toplumsal hayata dönük ritüel ve faaliyetleri değil, bireysel olarak icrâ ettikleri ibadetler de sıkı kontrol

32 Marmol, Historia de Rebellion, I, 148; Lea, İspanya Müslümanlarl, s. 224; İnân, Nihâye, s. 360; Reem F. Iversen, Prophecy and Politics: Moriscos and Christians in Sixteenth and Seventeenth Century Spain, Yayımlanmamış Doktora Tezi, Prınceton University 2002, s.158.

33 Marmol, Historia de Rebellion, I, 148; Lea, s. 224; İnân, Nihâye, s. 360; Iversen, Prophecy and Politics s. 158.

34 Verilen farklı rakamlar için bk. İnân, Nihâye, s. 316, 318; dn. 4.

35 Cardaillac, el-Moriskiyyûne'l-Endelüssiyyûn ve'l-Mesîhîyyûn, s.69. 
Katolik İspanyol İktidarınđa Endülüs Müslümanları'nın Kimlik Mücadelesi: Moriskolar Örneoği altında tutulmuştur. İçerisinde bulundukları bu durumu II. Bayezit'e gönderdikleri mektupda dile getirmişlerdir; Zorla din değiştirmek zorunda kaldıklarını, Kur'an-ı Kerim başta olmak üzere İslâmî tüm kitapların yakıldığını, namaz kılanların ve oruç tutanların ateşlerde yakıldıklarını, haksız bir şekilde mallarına el konulduğunu, Hz. Muhammed'e küfretmeye zorlandıklarını, ölülerinin eşek sırtlarında çöplüklere atıldıklarını, çocuklarına Hıristiyan akidesinin zorla öğretildiğini ve mescidlerin çöplük olarak kullanıldığını haber vermişlerdir. ${ }^{36}$

Assmann, hatırlama kültüründe ve sosyo-kültürel bellek pekiştirme tekniklerinde "bellek mekânlarının" önemine işaret eder. ${ }^{37}$ Kimliğin muhafaza edilmesinde, yenilenmesinde, inançların ve anıların anıtlaşmasında mekânların önemli bir yeri vardır. Zamanı durdurarak unutmayı engelleyen, ölümü adeta ölümsüzleştiren bu mekânların ${ }^{38}$ varlığı kimliğin devamında önemli bir işleve sahiptir. Bu sebeple, Moriskolar'ın hafıza mekânlarından cami ve mescidlerin tamamı ya yıkılmış ya da kiliseye tahvil edilmiştir. İslâm olmanın göstergesi kabul ettikleri mekânlar ${ }^{39}$ olan hamamlar ise, önce kapatılmış daha sonra ise tamamen yıkılmıştır. ${ }^{40}$

\section{b. Hatırlama}

İslâmî unsurların Moriskolar'ın bireysel ve toplumsal hayatından çıkarılmasına yönelik emir ve yasaklar, Moriskolar'ın kolektif hafızayı devreye sokarak "hatırlama" üzerinden İslâmî ritüelleri canlı tutma çabalarına yol açmıştır. Çünkü, hatırlama, bir anlamda bir topluluğa ruh veren bellekle ilgilidir. İnsan, ortak belleğin çerçeve-

\footnotetext{
36 Azmi Yüksel, "Endülüs'ten II. Bâyezîd'e Yazılan Anonim Bir Şiir", Belleten, LII/205 (Aralık 1998) s. 1575-1583.

37 Jan Assmann, Kültürel Bellek, Çev.: Ayşe Tekin, Ayrıntı Yayınları, İstanbul 2001, s.63.

38 Pierre Nora, Hafiza Mekânları, Çev.: Mehmet Emin Özcan, Dost Kitapevi Yayınları, Ankara 2006, s.32.

39 Cemâleddin, el-Müslimûne'l-münassârûn, s.372.

40 Lea, Simancas arşivinde karşılaştığ deki tüm hamamların yıkılmasının emredildiği, evinde veya başka bir yerde hamam olarak kullanılan yerleri muhafaza eden kişilere ilk seferde 50 gün zincirli hapis ve 100.000 maravidi para cezası, ikinci kez aynı suçu işlediklerinde bu cezanın iki katı, üçüncü kez işlediklerinde ise tüm malının yarısına el konularak 5 yıl kürek cezasıyla cezalandırılacaklarının belirtildiğini kaydeder, bk. Lea, İspanya Müslümanlarl, s. 226, dn.29.
} 
sine yerleştirilen ve kendileriyle alış-veriş içerinde bulunduğu şeyleri hatırlar. Bu nedenle, zayıfta olsa hatırlama kültürüne sahip olmayan bir topluluk tahâyyül etmek imkansızdır. İnsanın sosyalleşmesi sürecinde oluşan bellek, her zaman bir bireye aittir fakat, toplumsal olarak belirlenir. Bellek, sadece geçmişin korkularını değil, umutlarınının da hatırlanmasını sağlar. Unutulmamalıdır ki baskı ortamlarında hatırlama bir "direniş" biçimi olarak ortaya çıkar, mevcut gerçeklerden uzaklaştırıp, bu gerçeklerin iktidarını kısa süreliğine kıran bir "aracılık" olarak ortaya çıkar. ${ }^{41}$

Kimliklerini koruma azminde olan Moriskolar ise, İspanyol yöneticilerin büyük baskılarına rağmen, tarihin yeniden kurulması olarak nitelendirebileceğimiz toplumsal belleklerini canlı tutmaya, "hatırlamayı" ve "hatırlatıcı ritüelleri" hayatlarının bir parçası haline getirerek "unutmanın" önüne geçmeye çalışmışlardır. Çünkü onlar hatırlamanın "geçmişi güncele dönüştürme, atalarla dayanışma oluşturma anlamına" 42 geldiğinin, bilincindeydiler. Geçmişle irtibatlarını sağlayan ve kolektif hafızanın ürünü olan ritüeller, grup kimliğinin gelecek kuşaklara aktarılmasında önemli rol oynarlar. ${ }^{43}$

Öncelikle, dini hassasiyetlerini kaybetmeyen Moriskolar, içinde bulundukları zor şartlarda nasıl hareket edeceklerine dair fetvâ arayışına girmişlerdir. Dönemin önemli fakihlerinden Vehrânî'ye ${ }^{44}$ müracaat ederek durumlarıyla ilgili fetva/lar istemiş-

41 Assmann, Kültürel Bellek, s. 34, 40, 41, 75, 88.

42 Connerton, Toplumlar Nasil Anımsar?, s.73.

43 Assmann, Kültürel Bellek, s.60.

44 Ebü'l-Abbas Ahmed b. Ebi Cuma el-Mağrevî el-Vehrânî'nin Fas'in Oran kentinden veya Mağrev köyünden olduğu tahmin edilmektedir. Doğum tarihi hakkında kaynakların bilgi vermediği, verenlerin de XV. asrın ortalarını işaret ettiği Mağrevî'nin Berberî bir kabile olan Mağravî kabilesinden olabileceği belirtilmiştir. İlk eğitimini Oran'da tamamladıktan sonra Telemsan'a göç etmiş burada Malikî hukuku ve ilâhiyatıyla alâkalı konularda uzmanlaşmıştır. Telemsan'da Muhammed Senûsî'den ders görmüş, bir süre burada ders verdikten sonra da yeniden Oran'a dönmüştür. Daha sonra da Fez'e göç ederek burada hayata gözlerini yummuştur (1511); bk. Devin Stewart, "The Identity of "The Mufti of Oran", Abu'l-Abbas Ahmad b. Abi Jum'ah al-Maghrâwî al-Wahrânî (d. 917/1511), Al-Qantara (AQ), XXVII/2 (2006), s. 296. 
Katolik İspanyol İktidarınđa Enđülüs Müslümanları'nın Kimlik Mücadelesi: Moriskolar Örneoği

lerdir. Vehrânî, Moriskolar'a bulundukları ortamda tam olarak "takiyye" yapmalarını tavsiye etmiş, hayatta kalmak için çabalamalarını istemiştir. 45

Vehrâni'nin tavsiyeleri doğrultusunda hem bireysel hem de toplumsal hayatta İslâmın gereklerini asgari düzeyde yerine getirmeye çalışmışlardır. Abdest alma, namaz kılma, oruç tutma ve zekat verme gibi ibadetleri yerine getirirlerken, domuz eti yemek, şarap içmek ve murdar bir hayvanın etini yemekten imtina etmeye çalışmışlardır. Horcajo' da oturan Vela Núñez isimli Morisko, engizisyon tarafından domuz eti yememek ve şarap içmemekle suçlanmıştır. ${ }^{46}$ Ana de Figueroa'nın kölesi olan İsabel de Madrid isimli kadın kendisine Moro köpeği (moraperra) diye alaylı bir şekilde hitap edildiğinde, “Evet ben bir Moro'yum. Çünkü annem ve babam Moro idiler ve Moro olarak öldüler. Ben de Moro'yum ve Moro olarak ölmek zorundayım" diye mukâbelede bulunuyordu. ${ }^{47}$

Aile dışında, Moriskolar'ın İslâmı öğrenecek herhangi bir kanalın kalmamış olması, zamanla, okudukları duaların anlamını bilmeden namaz kılmalarına sebep olmuştur. Süreç içerisinde namaz hakkında bildikleri tek şey, atalarına ait bir ibadet şekli olduğudur. Arcos'ta yaşayan Maria de Gabriel isimli genç kız, sabah kalktığında, akşam yatarken ve gündüz vakti birkaç kez şu sözleri tekrar etmişti: "Rabbim Allah'dır. Muhammed O'nun peygamberidir. Kur'an rehberim, Ka'be kıblemdir". ${ }^{48}$

Moriskolar'ın baskılar sebebiyle en son bıraktığı ibadet oruç olmuştur. Ramazan orucunu tutmak için hilalin gözetlenmesine önem vermiş, ${ }^{49}$ bu kutsal ayda Hıristiyan komşuları tarafından yemeğe davet edildiklerinde ya iştah eksikliğini ya da henüz yemek yedik-

45 Bu fetvanın Aljamiado metninden İspanyolca'ya özet tercümesi için; bk. Pedro Longas, La Vida Religiosa de Los Moriscos, s. 305-307; ayrıca bk. İnân, Nihâye, s. 343343; L. Patrik Harvey, Muslims in Spain: 1500 to 1614, University of Chicago Press, Chicago, 2005, s. 61-63. Fetvanın içeriği için bk, Bilgin, Endülüs'teki Müslümanlar (Moriskolar), s.165-166

46 Cardaillac, Moriscos y Cristianos, s.32.

47 Cardaillac, Moriscos y Cristianos, s.24.

48 Mehmet, Özdemir, Endülüs Müslümanları, İlim ve Kültür Tarihi, Türkiye Diyanet Vakfı Yayınları, Ankara 1997, s. 135.

49 Cardaillac, el-Moriskiyyûne'l-Endelüsiyyûne'l Mesihiyyûn, s. 87; Özdemir, Endülüs Müslümanları, s. 137; Bilgin, Endülüs'teki Müslümanlar (Moriskolar), s.170. 
lerini bahane ederek oruç tutmaya devam etmişlerdir. Mesela, Francisco de Córdoba isimli Morisko bu şekilde davranmıştır. ${ }^{50}$ Çocuklarına domuz eti yememelerini ve şarap içmemelerini telkin eden Moriskolar, akşam eve geldiklerinde ağılarını koklayarak onları kontrol etmişlerdir. ${ }^{51}$

Toplumsal hayatta da kendi kimliklerinin kaybolmamasi/unutulmaması için ciddi anlamda gayret göstermişlerdir. Bu kapsamda, kilisede vaftiz edilen ve vaftiz ismi verilen çocuklar evlerine getirildikten sonra temiz suyla tüm vücudları yıkanıp, İslâmî isimler takmak için gizlice "fada" veya "fadas" ismi verilen merâsimler yapılmış, ${ }^{2}$ İslâm'ın göstergesi olduğu gerekçesiyle Katolik İspanyol devleti tarafından yasaklanan erkek çocukların sünnetine özel önem verilmiştir. ${ }^{53}$ Evlilik merâsimleri kiliselerde papazların huzurunda yapılmadığı sürece geçerli kabul edilmeyen Moriskolar, Hıristiyan evliliklerinde giyilen elbiseleri giyinip (vestidas de cristianas) ${ }^{54}$ kiliselerdeki zorunlu törenlerden sonra eve geldiklerinde İslâmî usüllere göre düğünlerini yapmışlardır. ${ }^{55}$ 1570' de Deza' da ikâmet eden Lope Guerrero isimli Morisko, kilisedeki törenden sonra evinde İslâmî usüllere göre bir merâsim düzenlemiştir. Merâsimde Kur'an'dan ayetler okunduktan sonra çocuğuna İslâmî bir isim verilmiş ve vaftiz ismi çocuktan kaldırılmıştır. ${ }^{56}$

Kilise tarafından "küfür" olarak değerlendirilen akraba evlilikleri (amca ve hala çocuklarıyla evlilik) Moriskolar arasında yaygın olarak yapılmıştır. ${ }^{57} \mathrm{Bu}$ tarz evlilik yapanlardan biri de María Fiñana isimli Morisko kadındı. María engizisyon mahkemesi tarafından kilise kanunları ve İspanyol toplumunun geleneklerine uymamakla suçlanmıştı. ${ }^{58}$

\footnotetext{
Cardaillac, Moriscos y Cristianos, s.26.

Cardaillac, el-Moriskiyyûne'l-Endelüsiyyûne'l-Mesihiyyûn, s. 32.

Ortiz-Vincent, Historia de los Moriscos, s. 91; Doncel, "Las Practicas Musulmanas de los Moriscos Anadaluces", s. 18; Cemâleddin, el-Müslimûne'l-münassârûn, s.352.

53 Ortiz-Vincent, Historia de los Moriscos, s. 102; Temîmî, "Vâkiu ve'l-Mustakbelu bahsu 'an Târîhi'l-Moriskiyyin el-Endelüsiyyîn", s.42

54 Julia Caro Baroja, Los Moriscos del Reino de Granada, Alianza Editorial, Madrid 2003, s.117; Luis Cardaillac, el-Moriskiyyûne'l-Endelüssiyyûn ve'l-Mesîhîyyûn, s.36.

55 Cemâleddin, el-Müslimûne'l-münassârûn, s.353.

56 Cardaillac, Moriscos y Cristianos, s.37.

57 Belkasım Dürârece, El-Endelüsiyyûne'l-Müslimûn ve Muhâkemetü't-Teftiş, elZikrâ hamsemie senetü li sukûtu Gırnata, 1492-1992, Zaghouan 1993, s. 72.

58 Cardaillac, Moriscos y Cristianos, s.38.
} 
Katolik İspanyol İktidarınđa Enđülüs Müslümanları'nın Kimlik Mücadelesi: Moriskolar Örneoği

Cenâze merâsimleri Moriskolar'ın toplumsal hatırlamayı canlı tuttuğu bir diğer ritüeldir. İslâmî usüllere göre cenazelerin defnedilmesini yasaklayan İspanyol yönetimi, Moriskolar'ın cenaze törenlerini kiliselerde yapmalarını ve cenazelerini Hıristiyan mezarlıklarına gömmelerini zorunlu hale getirmişti. ${ }^{59}$ Fakat, Moriskolar yasaklamalara rağmen mevtânın arkasından bir hafta boyunca Kur'an-1 Kerim okumaya devam etmiş, ölünün ruhunun evini ziyaret edeceği düşüncesiyle ruhunu teslim ettiği odayı 1şıklandırarak oraya sıcak su, ibrik, temiz bir bez ve seccade bırakmışlardir. ${ }^{60}$

Moriskolar'ın Arapça'nın sistematik olarak unutturulmasının önüne geçmek maksadıyla geliştirdikleri en önemli "hatırlama" ögesi, Endülüs'te XVII. asrın başlarına kadar konuşulan ve Arap harfleriyle yazılan İspanyolca anlamına gelen "Aljamiado" dilidir ${ }^{61}$. Araplar'ın genel olarak İspanyolca'nın yerine kullandıkları el-acemiyye (yabancı dil) kelimesi İspanyolca'ya girerek "Aljamia" şeklini almıştır. Daha sonraları da İspanyollar'ın dışında kalan Müslümanlar'ın ve Yahudiler ile Arap kültürünü benimsemiş İspanyollar'ın konuştukları, Arap harflerle yazılan melez İspanyol lehçesinin adlandırılması için kullanılmıştır. ${ }^{62}$

Aljamiado eserlerini yazanlar, Moriskolar'ın Arapça'yı unuttuklarının farkındadırlar. Ailelerinden öğrendikleri bazı Arapça duaları okuyabiliyorlardı, fakat bu duaların anlamların bilmiyorlardı. Matheo Perez gibi Arapça bilen Moriskolar hem Arapça'nın öğretilmesine çaba sarfediyor hem de İspanyolca'ya çeşitli dinî metinleri tercüme ediyorlardı. İslâm dininin bilinmesi, öğretilmesi, cehaletin tanınması ve bilinmesi, dosdoğru yolun ve Resulullah'ın sünnetinin anlaşılması, haram-helâl konularının öğrenilmesi ile Hıristiyan akaidinin hatalı olduğunun ${ }^{63}$ bilinmesi amacıyla yazılan Aljamiado

\footnotetext{
59 Ortiz-Vincent, Historia de los Moriscos, s. 102.

60 Pedro Longas, el-Hayâtü'd-dîniyye li'l-Mûriskiyyîn el-Endelüsiyyîn, Çev.: Cemal Abdurrahman, Zaghouan 1993 s. 284-302.

61 Cemâleddin, el-Müslimûne'l-münassârûn, s.355.

62 Sargon Erdem, “Aljamia”, DİA, II, 465; C. F. Seybold, “Aljamia”, İA, I, 359

63 Cardaillac, Moriscos y Cristianos, s. 73.
} 
eserler Hıristiyan yönetimindeki Moriskolar'ın dinî ve kültürel yaşamlarıyla alâkalı iki kaynaktan (diğeri engizisyon mahkeme kayıtları ve devlet arşivleri) biri olmuştur. ${ }^{64}$

\section{Sonuç}

İktidarın, insanların ruhlarına kadar işlediği pastoral iktidar, kendisini gerçekleştirmek için, bireylerin gözetilmesine, kapatılmasına ve cezalandırılmasına önem vermiştir. Eğitim müesseseleri, mahkemeler, hapishaneler hep bu amacı gerçekleştirmek için inşâ edilmiştir. Bu kapsamda, Katolik İspanyol iktidarı, Moriskolar'ın, eğitim-öğretim faaliyetleri için kiliseler inşâ etmiş, eğitim faaliyetleri sonucunda, şayet, iktidarı gerçekleşmemiş (yani Katolik iman gerçek anlamda özümsenmemiş) ise, "şeytanın mahkemeleri" olarak isimlendirilen engizisyon mahkemelerini devreye sokmuştur.

Namaz kılmaları, oruç tutmaları, Arapça konuşma ve yazmaları, erkek çocuklarını sünnet etmeleri, başlarına, ellerine ve ayaklarına kına yakmaları, İslâm'a ait olduklarını gösteren elbise giymeleri, Mağribî usüllerle düğün yapmaları, İslâmî isimleri çocuklarına vermeleri, hamama gitmeleri yasaklanan Moriskolar ise "takiyye" yapmayı hem bireysel hem de toplumsal hayatta bir yaşam tarzı olarak benimsemişlerdir. Moriskolar, dinî ve sosyo-kültürel kimliklerinin kaybolmaması ve toplumsal hafıza kaybına uğramamak için, "hatırlamaya" ve "hatırlatıcı" ritüellere fırsat buldukları her zaman ve zeminde başvurmuşlardır. Özellikle, sosyal belleğin en önemli koruyucusu ve taşıyıcısı olan Arap dilinin korunması amacıyla geliştirdikleri, İspanyolca'nın Arap harfleriyle yazımı olan Aljamiado dili özenle korunmaya çalışılmıştır.

Kimliğin önemli unsurlarından biri olan dinî inanç ve ibadetlerin, günlük yaşamda yasaklanması ve görünür olmaktan çıkarılmaları, bireysel alandan çıkarıldıkları manasına gelmemektedir. Bu durumun en güzel örneklerinden biri "şeklen Hıristiyan oldukları" kabul edilen Moriskolar'ın gerçekte Müslüman kalmaya devam etmeleridir. Bu sebeple, Katolik İspanyol yönetimi, Moriskoları hiçbir zaman "gerçek Katolik" kabul etmemiş, onları "öteki medeniyete" ait oldukları gerekçesiyle nihayetinde İspanya dışına sürgün etmiştir (1018-1023/1609-1614). Faucault'un iktidarı sağlama yöntemleri

64 Riza Mâmî, "el-Mahtutâtu'l-Alhâmiyâdiyye Kemasdari târîhî bi'n-nisbeti li'lkarni's-Sâdisi 'Aşere", Las Practicas Musulmanas de los Moriscos Andaluces, Zaghouan 1991, s. 151. 
Katolik İspanyol İktidarınđa Enđülüs Müslümanları'nın Kimlik Mücadelesi: Moriskolar Örneoği olarak değerlendirdiği yöntemler, Moriskolar üzerinde uygulanmış fakat, Moriskolar'ın geliştirdikleri pasif ve gizli direnişle sonuçsuz bırakılmışlardır. Bu durumun en güzel kanıtı ise, on yıllar geçmesine rağmen sağlanamayan Katolik iktidarın, bedenin kanserli hücreleri olarak telakkî ettiği Moriskoları tamamen İspanya'dan koparmasidir.

\section{Kaynakça}

Assmann, Jan, Kültürel Bellek, Çev.: Ayşe Tekin), Ayrıntı Yayınları, İstanbul 2001.

Baroja, Julia Caro, Los Moriscos del Reino de Granada, Alianza Editorial, Madrid 2003.

Bilgin, Feridun, Nasrîler (Benî Ahmer) Sonrasında Endülüs'teki Müslümanlar (Moriskolar), Yayımlanmamış Doktora Tezi, MarmaraÜniversitesi Sosyal Bilimler Enstitüsü, İstanbul 2010.

, "Endülüs'te Kalan Son Müslümanların (Moriskolar) İspanya'dan Sürgünü (1609-1614)", Dinbilimleri Akademik Araştırmalar Dergisi, C. XIII, sayı: II, s.37-61.

Bleda, Jaime, Coronica de Los Moriscos de España, Universitad de Valencia, Valencia 2001.

Braudel, Fernand, Akdeniz ve Akdeniz Dünyası, Çev.: Mehmet Ali Kılıçbay, İmge Yayınları, İstanbul 1994, II.

Burin y Sandoval, Antonio Gallego, Alfonso Gámir, Los Moriscos del Reino de Granada, Según Sínodo de Guadix de 1554, Granada 1996.

Cardaillac, Louis, Moriscos y Cristianos un Enfrentamiento Polemico (1492-1640), Fondo de Cultura Economica, Madrid 1979.

------------, el-Moriskiyyûne'l-Endelüsiyyûne'1 Mesihiyyûn, elMücâbihâtü'l-Cedeliyye (1492-1640), Trc.: Abdülcelil Temîmî), Zaghouan 1989.

Carvajal, Luis de Marmol, Historia de Rebellion y Castigo de los Moriscos del Reino de Granada, Madrid 1797, I.

Cemâleddîn, Abdullah Muhammed, Müslimûne'l-münassârûn evi'l-Mûriskiyyûne'l-Endelüsiyyûn: Safha mühime min târîhi'l-müslimîn fi'lEndelüs, Dârüs's-Sahve, Kāhire 1991.

Connerton, Paul, Toplumlar Nasıl Anımsar?, Çev.: Alaeddin Şenel, Ayrıntı Yayınları, İstanbul 1999.

Doncel, Juan Aranda, “Las Practicas Musulmanas de los Moriscos Anadaluces a Traves de las Relaciones de Causas del Tribunal de la Inquis1cion de Cordoba, Las Practicas Musulmanas de los moriscos Andaluces, (1492-1609)", Actas de 111 simposio internacional de estudios moriscos, Zaghouan, November 1991. 
Dürârece, Belkâsım, El-Endelüsiyyûne'l-Müslimûn ve Muhâkemetü't-Teftiş, el-Zikrâ hamsemie senetü li sukûtu Gırnata, 1492-1992, Zaghouan: 1993.

E. Lévi-Provençal "Moors". Encyclopaedia of Islam. P. Bearman ,Th. Bianquis, C. E. Bosworth, E. van Donzel and W. P. Heinrichs (Ed.). Brill 2008, VII, 235-236.

Epalza, Mikel de, Los moriscos antes y después de la expulsión, Editorial Mapfre, Madrid 1992; http://www.cervantesvirtual.com/FichaObra (12 Eylül 2008).

Erdem, Sargon, “Aljamia”, DİA, II, 465.

Harvey, L. Patrik, Muslims in Spain : 1500 to 1614, University of Chicago Press, Chicago 2005.

Iversen, Reem F., Prophecy and Politics : Moriscos and Christians in Sixteenth and Seventeenth Century Spain, Yayımlanmamış Doktora Tezi, Princeton University 2002.

İnân, Muhammed Abdullah, Nihâyetü'l-Endelüs ve târîhu'l-Arabi'l-mutenassırîn, Mektebetü'l-Hancî, Kahire 1987.

Foucault, Michel, Özne ve İktidar, Çev.: Işık Ergüden-Osman Akınay, Ayrıntı Yayınları, İstanbul 2011.

------------------, İktidarın Gözü, Çev.: Işık Ergüden, Ayrıntı Yayınları, İstanbul 2012.

------------------, Büyük Kapatılma, Çev.: Işık Ergüden, Ferda Keskin, Ayrıntı Yayınları, İstanbul 2011.

Kettanî, Ali el-Muntasır, İnbiâsü'l-İslâm fi'l-Endelüs, Câmiatü'l-İslâmiyyeti'l-Âlemiyye, İslamabad 1992.

Lea, H. Charles, İspanya Müslümanları, Hıristiyanlaştırılmaları ve Sürülmeleri, Çev.: Abdullah Davudoğlu, Inkılâb Yayınları, İstanbul 2006.

Longas, Pedro, La Vida Religiosa de Los Moriscos, Universidad de Granada, Granada 1998.

el-Hayâtü'd-dîniyye li'l-Mûriskiyyîn el-Endelüsiyyîn, Çev.: Cemal Abdurrahman), Zaghouan 1993.

Mâmî, Rıza, "el-Mahtutâtu'l-Alhâmiyâdiyye Kemasdari târîhî bi'n-nisbeti li'l-karni's-Sâdisi 'Aşere”, Las Practicas Musulmanas de los Moriscos Andaluces, Zaghouan 1991.

Moreno, Angel A. Amy, The Spanish Treatment of Moriscos as a Model for the Treatment of Native Americans, Yayımlanmamış Doktora Tezi, Boston University 1982.

Nora, Pierre, Hafıza Mekânları, Çev.: Mehmet Emin Özcan, Dost Kitapevi Yayınları, Ankara 2006.

Ortiz, Antonio Domínguez - Bernard Vincent, Historia de los Moriscos: vida y tragedia de una minoría, Alianza Editorial, Madrid 1997.

--------------, Târîhu Müslimi'l-Endelüs - Mûriskiyyûn (Hayâtu ve Me'sâtu Ekâliyye, Trc.: A.Salih Taha, Katar: 1998. 
Katolik İspanyol İktidarınđa Endülüs Müslümanları'nın Kimlik Mücadelesi: Moriskolar Örneoği

Özdemir, Mehmet, Endülüs Müslümanları, İlim ve Kültür Tarihi, Türkiye Diyanet Vakfı Yayınları, Ankara 1997.

Pertegás, Rodrigo José, “La morería de Valencia. Ensayo de descripción topográfico histórica de la misma", Edición digital a partir de Boletín de la Real Academia de la Historia, tomo 86 (1925), Biblioteca Nacional, Madrid 2010, pp. 229-251.

Seybold, C. F., "Aljamia”, İA, I, 359.

Stewart, Devin, “The Identity of "The Mufti of Oran", Abu'l-Abbas Ahmad b. Abi Jum'ah al-Maghrâwî al-Wahrânî (d. 917/1511), Al-Qantara (AQ), XXVII/2 (2006), s. 265-301.

Temîmî, Abdülcelil, “Vâkiu ve'l-Mustakbelu bahsu 'an Târîhi'l-Moriskiyyin el-Endelüsiyyîn, Las Practicas Musulmanes de Los Moriscos Andaluces (1492-1609)", Actas de 111 simposio internacional de estudios moriscos, Zaghouan 1991.

Yılmaz, Ahenk, "Bellek Topografyasında Özgürlük: Gelibolu Savaş Alanları ve Mekânsal Bir Deneyim Olarak Hatırlama", Nasıl Hatırlıyoruz? Türkiye'de Bellek Çalışmaları içinde (Haz.: Leyla Neyzi, Türkiye İş Bankası Kültür Yayınları, İstanbul 2011, s.187-217.

Yüksel, Azmi, “Endülüs'ten II. Bâyezîd'e Yazılan Anonim Bir Şiir", Belleten, LII/205 (Aralık 1998) s. 1575-1583. 


\section{MiLel VE NiHAL}

inanç, kültür ve mitoloji araştırmaları dergisi

Cilt/Volume: 11 Sayı/Number: 1 Ocak - Haziran / January - June 2014 ISSN: 1304-5482

Bu dergi uluslararası EBSCO HOST Research Databases veri indeksi ve TÜBITTAK-ULAKBİM Sosyal ve Beşeri Bilimler Veri Tabanı tarafından taranmaktadır.

\section{Sahibi / Owner}

Milel ve Nihal Eğitim, Kültür ve Düşünce Platformu Derneği adına Şinasi Gündüz

$$
\begin{gathered}
\text { Yazı İşleri Sorumlusu / Legal Representative } \\
\text { Yasin Aktay }
\end{gathered}
$$

\section{Editör / Editor}

Şinasi Gündüz

Editör Yrd. / Co-Editor

Cengiz Batuk

\section{Yayın Kurulu/ Editorial Board*}

Alpaslan Açıgenç, Ayaz Akkoyun, Yasin Aktay, Mahmut Aydın,

Cengiz Batuk, Şinasi Gündüz, İbrahim Kayan, Hakan Olgun, Necdet Subaşı,

\section{Burhanettin Tatar}

\section{Danışma Kurulu/Advisory Board}

Baki Adam (Prof. Dr., AÜ); Mohd. Mumtaz Ali (Prof. International Islamic U. Malezya); Adnan Aslan (Prof.Dr., Süleyman Şah Ü.); Kemal Ataman (Doç.Dr., Uludağ Ü.); Mehmet Akif Aydın (Prof. Dr., Marmara Ü.); Yılmaz Can (Prof. Dr., OMÜ); Ahmet Çakır (Doç. Dr., OMÜ); Mehmet Çelik

(Prof. Dr., Celal Bayar Ü.); Waleck S. Dalpour (Prof. University of Maine at Farmington); İsmail

Engin (Dr., Berlin); Cemalettin Erdemci (Prof.Dr. YYÜ); Tahsin Görgün (Prof.Dr., 29

Mayıs Ü.) Ahmet Güç (Prof.Dr., Uludağ Ü.); Recep Gün (Doç. Dr., OMÜ); Ö. Faruk Harman

(Prof.Dr., Mar.Ü.); Erica C.D. Hunter (Dr., Cambridge U.); Mehmet Katar (Prof. Dr., A.Ü.);

Mahmut Kaya (Prof. Dr., İ.Ü.); Sadık Kılıç (Prof.Dr., Atatürk Ü.); Şevket Kotan (Y.Doç.Dr., İ.Ü.); İlhan Kutluer (Prof.Dr., Mar. Ü.); George F. McLean (Prof. Catholic Univ., Washington DC); Ahmet Yaşar Ocak (Prof. Dr., Hacettepe Ü.); Jon Oplinger (Prof. University of Maine at Farmington); Ömer Özsoy (Prof.Dr., Frankfurt U.); Roselie Helena de Souza Pereira (Mestre em

Filofia-USP; UNICAMP Brasil); Ekrem Sarıkçıŏlu (Prof.Dr., SDÜ); Hüseyin Sarıŏlu (Prof.Dr.,

İÜ); Bobby S. Sayyid (Dr. Leeds U.); Mustafa Sinanoğlu (Prof.Dr., 29 Mayıs Ü.); Mahfuz Söylemez

(Prof.Dr. IÜ); Necdet Subaşı (Y.Doç.Dr., DİB); Bülent Şenay (Prof.Dr., UÜ); İsmail Taşpınar

(Prof.Dr. Mar.Ü.); C. Sadık Yaran (Prof.Dr., OMÜ); Ali Murat Yel (Prof.Dr., Fatih Ü.); Hüseyin Yılmaz (Doç.Dr., YYÜ); Ali İhsan Yitik (Prof. Dr., DEÜ)

* Soyadına göre alfabetik sıra / In alphabetical order

Kapak ve Sayfa Tasarımı / Cover \& Page Design

İnan Avc1

Baskı / Publication

Ladin Ofset - İstanbul, Mart 2015

2.Mat. Sit. 3 NB 15 Topkapı İstanbul / İsmail Tüz 02125012418

Yönetim Yeri / Administration Place

Milel ve Nihal Eğitim, Kültür ve Düşünce Platformu Derneği

Fevzipaşa Cad. Şehit Mehmet Sarper Alus Sok. No: 5, K.: 3, Tel: (0212) 5339731 Fatih/İstanbul www.milelvenihal.org e-posta: dergi@milelvenihal.org

Milel ve Nihal yılda iki sayı olarak altı ayda bir yayımlanan uluslararası hakemli bir dergidir. Milel ve Nihal' de yayımlanan yazıların bilimsel ve hukuki sorumluluğu yazarlarına aittir. Yayım dili Türkçe ve İngilizce'dir. Yayımlanan yazıların bütün yayın hakları Milel ve Nihal'e ait olup, yayıncının izni olmadan kısmen veya tamamen basılamaz, çoğaltılamaz ve elektronik ortama taşınamaz. Yazıların yayımlanı yayımlanmamasından yayın kurulu sorumludur. 


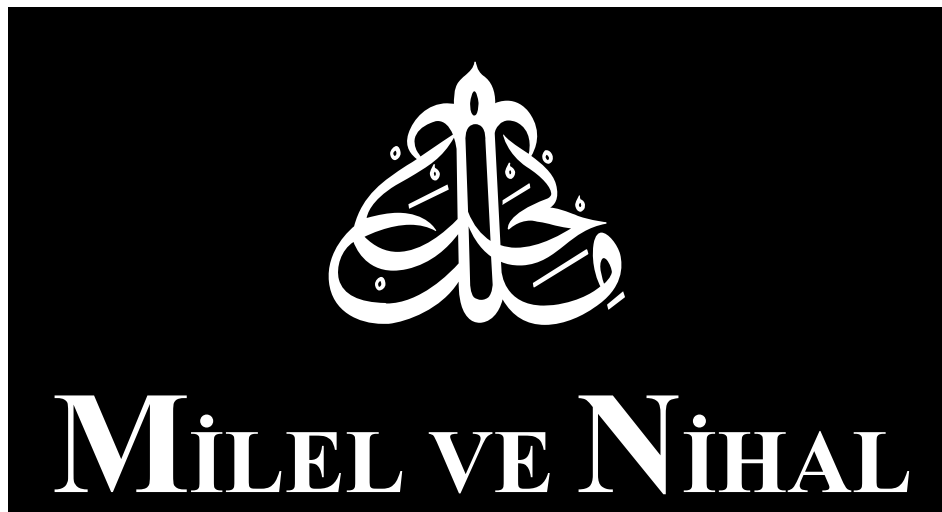

inanç, kültür ve mitoloji araştırmaları derogisi

ISSN: 1304-5482

Cilt/Volume: 11 Sayı/Number: 1

Ocak - Haziran / January - June 2014 